Check for updates

Cite this as: $B M J 2020 ; 371: m 4123$ http://dx.doi.org/10.1136/bmj.m4123 Published: 29 October 2020

\section{The BMJ Interview: Tim Spector on how data can arm us against covid-19}

We have amended this article (BMJ 2020;371:m3921, doi:, published 14 October 2020) to note that anosmia was first identified as a covid symptom by clinical reports from Italy, Belgium, and a group of UK consultants led by Claire Hopkins, rather than by the Covid Symptom Study app. 